\title{
Energi Mandiri dengan Pemanfaatan Limbah Cair pada Industri Pabrik Kelapa Sawit
}

\author{
Daniel Pasaribu' ${ }^{1}$, Endang Kusdiyantini' ${ }^{2}$ \\ ${ }^{1}$ Magister Energi, Sekolah Pascasarjana, Universitas Diponegoro; \\ ${ }^{2}$ Departemen Biologi, Fakultas Sains dan Matematika, Universitas Diponegoro;
}

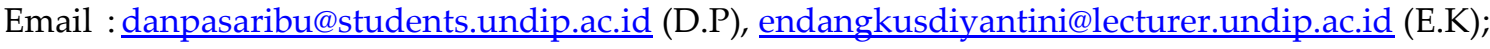

\begin{abstract}
Abstrak : Limbah merupakan permasalahan yang cukup serius di dunia industri kelapa sawit dan berdampak merusak lingkungan. Sehingga ditemukan teknologi biogas untuk mengatasi limbah cair (POME) dan dimanfaatkan untuk menghasilkan listrik. Teknologi tank reaktor cukup efektif dalam penanganan limbah cair (POME) untuk menghindari gas metan terlepas ke udara atmosfir. Pengembangan teknologi biogas di Indonesia terus dilakukan dari pendekatan skala besar dan kecil. Dari kapasitas produksi pabrik sebesar 30 ton/jam Tandan Buah Segar (TBS) dapat menghasilkan tenaga listrik sebesar 1 MW dari PLT Biogas (PLTBg).
\end{abstract}

Kata Kunci : Energi, biogas, POME, kelapa sawit

\section{Pendahuluan}

Biogas adalah gas yang mudah terbakar (flammable) yang dihasilkan dari proses fermentasi (pembusukan) bahan-bahan organik oleh bakteri-bakteri anaerob (bakteri yang hidup dalam kondisi tanpa oksigen yang ada dalam udara). Bahan-bahan organik adalah bahan-bahan yang dapat terurai kembali menjadi tanah, misal sampah dan kotoran hewan (sapi, kambing, babi, dan ayam). Fermentasi terjadi secara alami dalam waktu yang lama. Biogas berbeda dengan bahan bakar fosil dan dapat selalu diperbaharui.

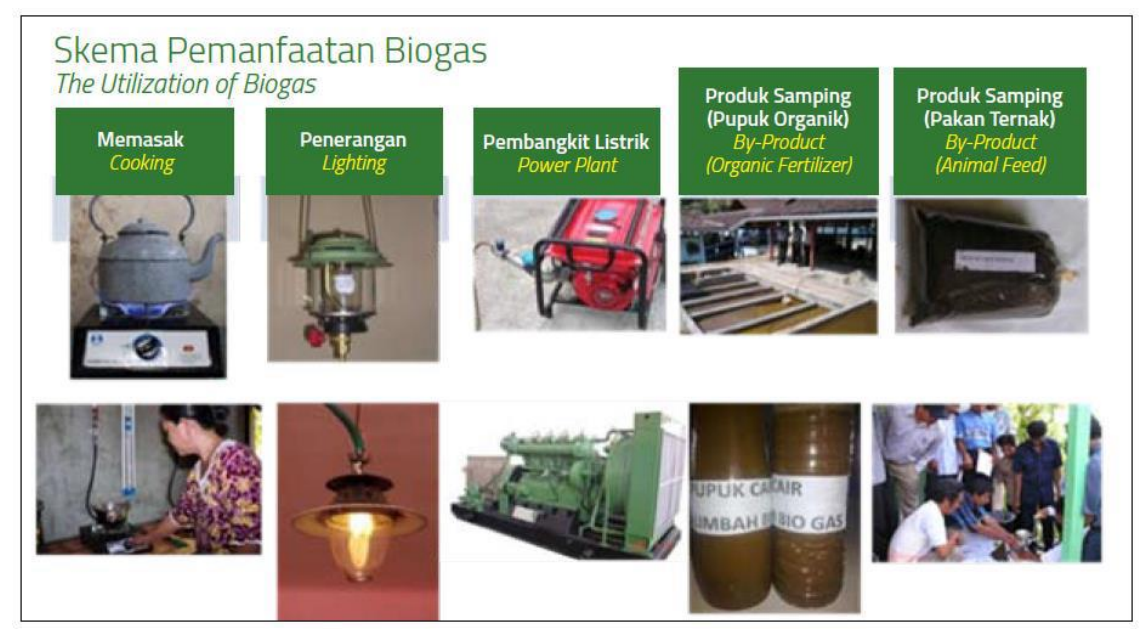

Gambar 1. Skema Pemanfaatan Biogas 
Biogas juga dapat dimanfaatkan untuk berbagai keperluan, diantaranya yaitu :

1) Dapat digunakan untuk kompor rumah tangga, penerangan, pemanas air, dan lainnya.

2) Digunakan untuk keperluan misalnya pemanas air, pemanas udara, pengering, dan lainnya.

3) Dapat untuk menggerakkan motor bakar, turbin.

\section{Dasar Teori}

Biogas mayoritas mengandung gas methan $\left(\mathrm{CH}_{4}\right)$ dan karbondioksida $\left(\mathrm{CO}_{2}\right)$, dan beberapa kandungan senyawa lain yang jumlahnya kecil diantaranya hidrogen sulfida $\left(\mathrm{H}_{2} \mathrm{~S}\right)$, ammonia $\left(\mathrm{NH}_{3}\right)$, hidrogen $\left(\mathrm{H}_{2}\right)$, serta oksigen $\left(\mathrm{O}_{2}\right)$. Komposisi biogas secara umum ditampilkan dalam tabel 1.

Tabel 1.

Komposisi Biogas Secara Umum

\begin{tabular}{lc}
\hline \multicolumn{1}{c}{ Komponen } & Persentase $(\%)$ \\
\hline Metana $\left(\mathrm{CH}_{4}\right)$ & $55-75$ \\
Karbon dioksida $\left(\mathrm{CO}_{2}\right)$ & $25-45$ \\
Nitrogen $\left(\mathrm{N}_{2}\right)$ & $0-0,3$ \\
Hidrogen $\left(\mathrm{H}_{2}\right)$ & $1-5$ \\
Hidrogen $\mathrm{Sulfida}\left(\mathrm{H}_{2} \mathrm{~S}\right)$ & $1-5$ \\
Oksigen $\left(\mathrm{O}_{2}\right)$ & $0,1-0,5$ \\
\hline
\end{tabular}

Energi yang terkandung dalam biogas tergantung dari konsentrasi methan $\left(\mathrm{CH}_{4}\right)$. Semakin tinggi kandungan methan maka semakin besar pula nilai kalor pada biogas. Peformansi biogas dapat ditinggikan dengan beberapa parameter yaitu : Menghilangkan hidrogen sulphur, kandungan air dan karbondioksida $\left(\mathrm{CO}_{2}\right)$. Kandungan yang terdapat dalam biogas merupakan hasil dari proses metabolisme mikroorganisme. Kandungan metana pada biogas lebih dari $45 \%$ cenderung mudah terbakar dan ini tergolong kategori bahan bakar yang baik karena nilai kalor nya tinggi. Kandungan $\mathrm{CO}_{2}$ dalam biogas ternyata berpengaruh terhadap performansi pembakaran karena dapat mengurangi nilai kalor bakar dari biogas tersebut. Kandungan $\mathrm{H}_{2} \mathrm{~S}$ dalam jumlah yang banyak dapat menyebabkan korosi pada peralatan dan perpipaan.

Tabel 2.

\begin{tabular}{lc}
\multicolumn{2}{c}{ Rasio C/N untuk Beberapa Bahan Organik } \\
\hline Jenis Kotoran & Rasio C/N \\
\hline Urine & 0,8 \\
Kotoran Sapi & $10-20$ \\
Kotoran Babi & $9-13$ \\
Kotoran Ayam & $5-8$ \\
Kotoran Kambing & 30 \\
Kotoran Manusia & 8 \\
Jerami Padi - Padian & $80-140$ \\
Jerami Jagung & $30-65$ \\
Rumput Hijau & 12 \\
Sisa Sayuran & 35 \\
\hline
\end{tabular}


Biogas dapat diproduksi dari bahan organik yang mengalami fermentasi anaerob. Di Indonesia pada umumnya bahan organiknya berasal dari kotoran hewan dan limbah cair pabrik kelapa sawit. Bahan organik yang diproses sangat mempengaruhi performansi biogas yang dihasilkan. Pemilihan bahan biogas dapat ditentukan dari perbandingan kadar C (karbon) dan N (nitrogen) dalam bahan tersebut. Tabel 2 menunjukkan rasio $\mathrm{C} / \mathrm{N}$ untuk beberapa jenis bahan organik. Bahan organik yang umumnya mampu menghasilkan kualitas biogas yang tinggi mempunyai rasio C/N sekitar $20-30$ atau $20-25$.

\section{Teknologi Pengolahan POME}

Saat ini pengelolaan POME dengan hanya menggunakan kolam terbuka sudah jarang diterapkan karena gas methane langsung terlepas ke atmosfer sehingga kurang ramah lingkungan. Teknologi pengolahan POME yang dewasa ini, diantara teknologi yang baru itu adalah membran dan terakhir terdengar dengan elektrokoagulasi. Munculnya atau adanya perkembangan teknologi pengelolaan.

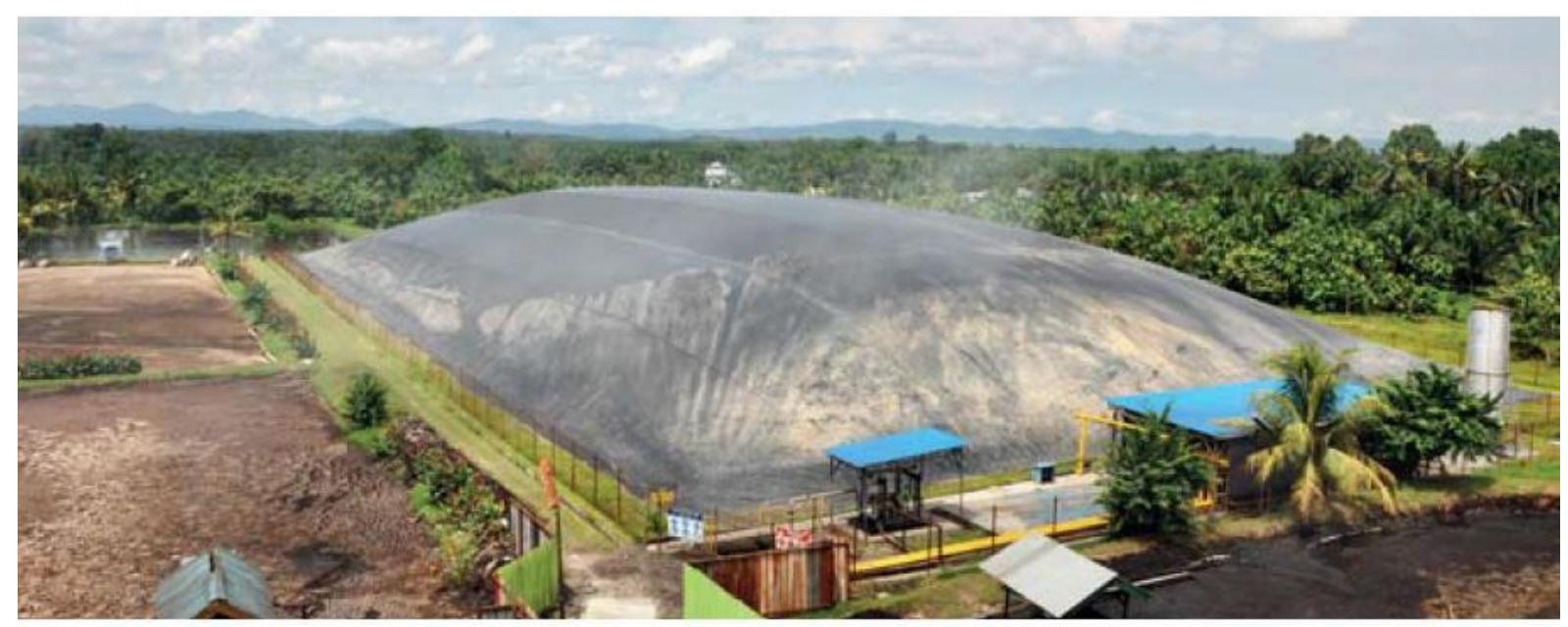

Gambar 2. PLTBg berbasis POME

Saat ini terdapat beberapa teknologi pengelolaan POME selain sistem kolam terbuka. Adapun teknologi itu adalah sebagai berikut:

1) Dengan menggunakan kolam aerobic (aerobic pond). Teknologi ini untuk menghindari terbentuknya gas metan.

2) Teknologi pengeringan (drying process), teknologi ini tidak sesuai karena memerlukan biaya dan energi yang besar untuk menguapkan air dalam POME.

3) Aplikasi tanah (land application), sistem ini tidak disarankan karena memerlukan biaya yang cukup besar.

4) Penggunaan tandan kosong kelapa sawit menjadi kompos, POME digunakan sebagai bahan penyiram pada proses pengomposan tandan kosong kelapa sawit. Teknologi ini cocok diterapkan, namun teknologi ini memerlukan sedikit investasi yang tinggi tetapi mendapat keuntungan dengan hasil penjualan kompos. 
Vol. 2, No. 3, pp $163-169$

doi: 10.14710/jebt.2021.11163

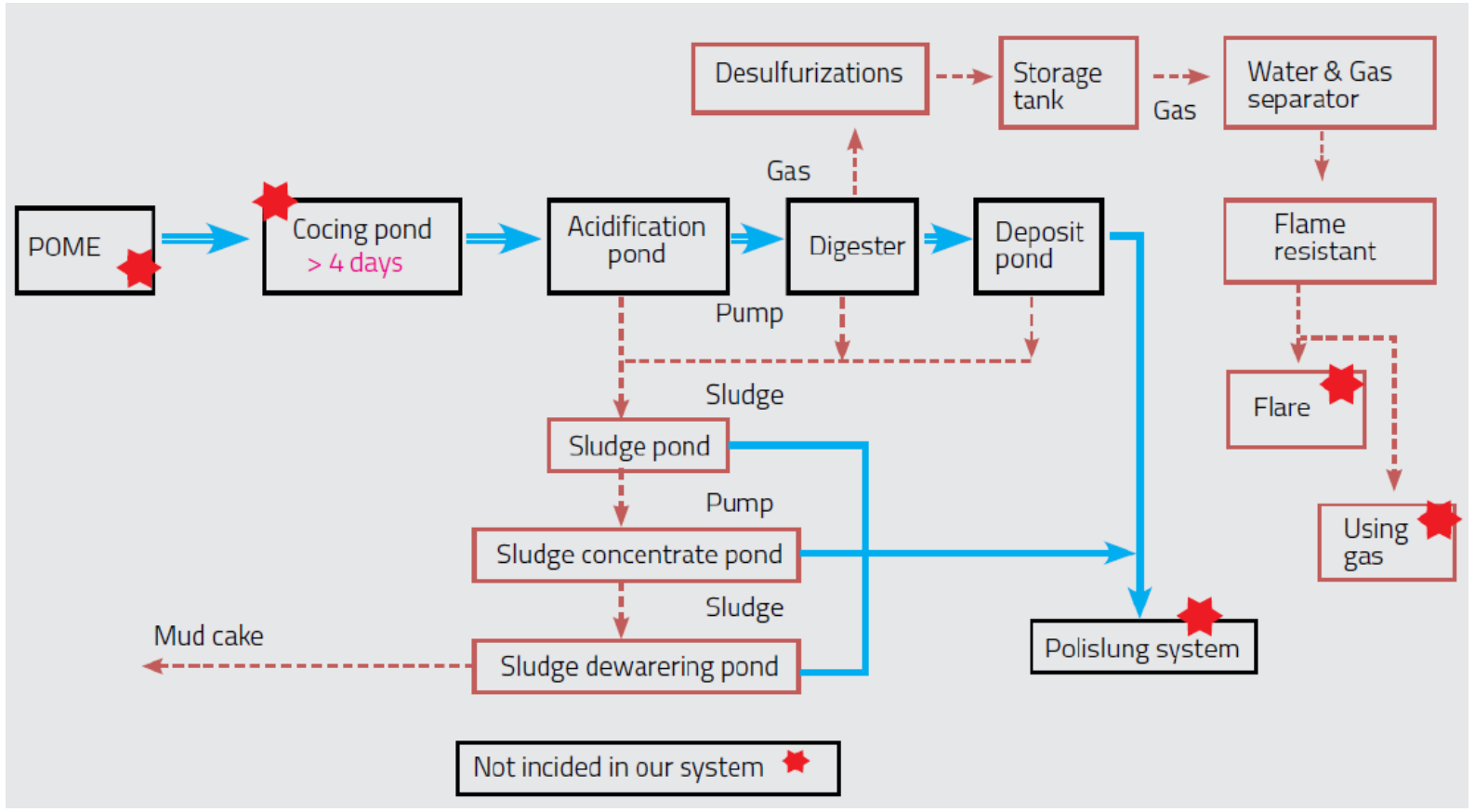

Gambar 3. Teknologi POME

Teknologi penangkapan gas metana ada yang membuat' tangki (biogas reactor) dengan menutup permukaan kolam limbah menggunakan penutup berbahan parasut (covered lagoon).

Tabel 3.

\begin{tabular}{lc}
\multicolumn{2}{c}{ Komposisi Kimia Limbah Pabrik Kelapa Sawit } \\
\hline \multicolumn{1}{c}{ Komponen } & Berat Kering $(\%)$ \\
\hline Ekstraksi dengan Ether & 31,6 \\
Protein $(\mathrm{N} \times 6,25)$ & 8,2 \\
Serat & 11,9 \\
Ekstraksi tanpa N & 34,2 \\
$\mathrm{Abu}$ & 14,1 \\
$\mathrm{P}$ & 0,24 \\
$\mathrm{~K}$ & 0,99 \\
$\mathrm{Ca}$ & 0,97 \\
$\mathrm{Mg}$ & 0,30 \\
$\mathrm{Na}$ & 0,08 \\
Energi $(\mathrm{kcal} / 100 \mathrm{gr})$ & 454 \\
\hline
\end{tabular}

Karakteristik limbah kelapa sawit memiliki komposisi kimia yang mengandung unsur hara yang dapat dimanfaatkan untuk pupuk dan bahkan digunakan untuk ramuan makanan ternak. 
Vol. 2, No. 3, pp $163-169$

doi: $10.14710 /$ jebt.2021.11163

\section{Hasil dan Pembahasan}

\subsection{Pengembangan Biogas}

Pendekatan program yang dilaksanakan pemerintah dalam melakukan pengembagan biogas, terbagi menjadi 2 klasifikasi, yaitu:

1) Berdasarkan Skala Pengembangan:

- Skala kecil/skala rumah tangga, biasanya untuk keperluan memasak dan penerangan.

- Skala besar, biasanya digunakan untuk pembangkitan listrik.

2) Berdasarkan Jenis Pengusahaan:

- Non-komersialisasi

Diterapkan untuk daerah-daerah yang belum melakukan pengembangan biogas.

Dimaksudkan untuk memberikan contoh langsung kepada masyarakat.

- Semi-komersialisasi

Kelanjutan dari tahap percontohan dengan mengkombinasikan antara kemampuan dan tanggung jawab oleh masyarakat. Subsidi diberikan hanya sebagian untuk meningkatkan rasa memiliki dan menjamin keberlanjutan. contoh Program BIRU (Biogas Rumah Tangga).

- Komersialisasi

Diterapkan oleh sektor swasta. Pemerintah hanya bersifat memfasilitasi, misalnya dalam aspek jaminan kualitas, pengoperasian, keamanan, tarif, dan lain-lain.

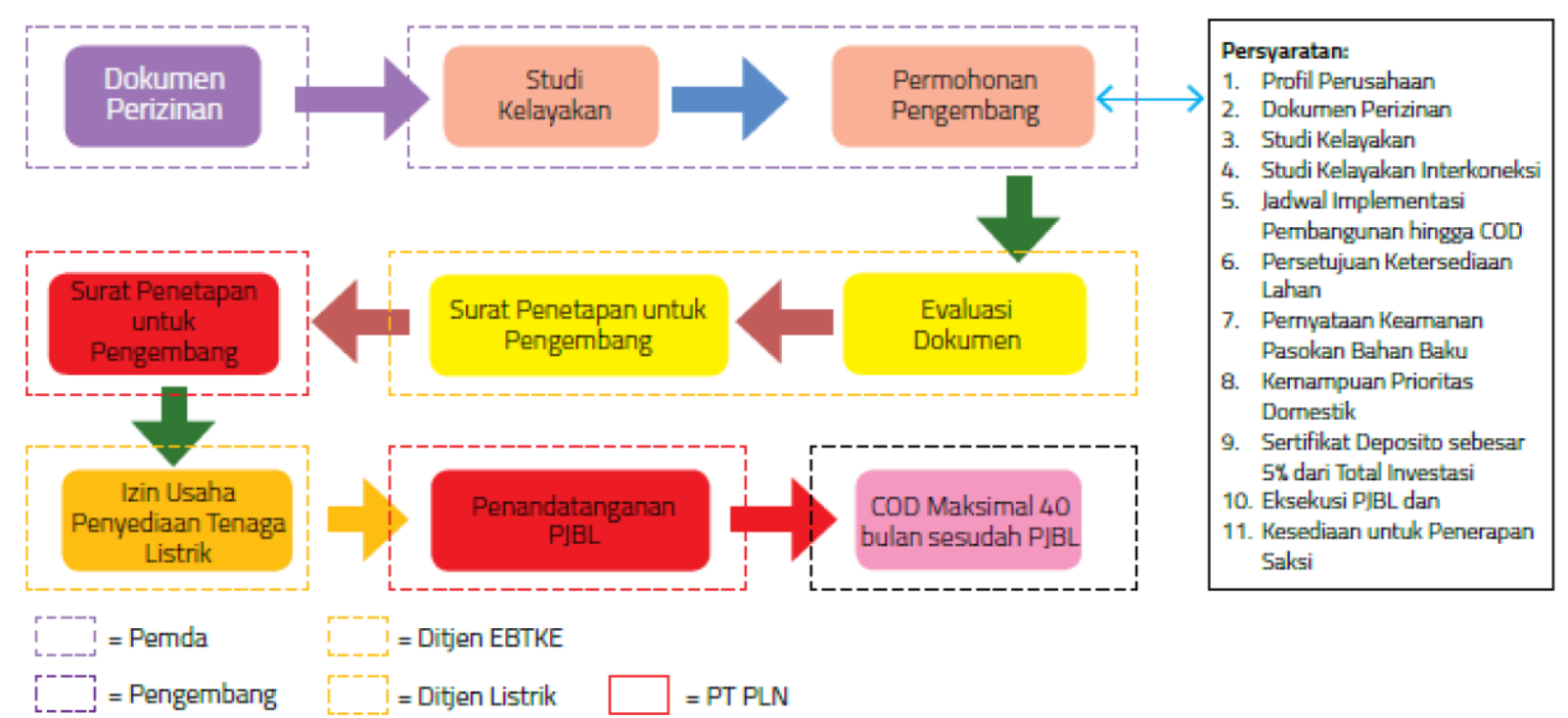

Gambar 4. Skema Pengajuan Pengembangan Pembangkit Listrik Tenaga Biogas

\subsection{Peluang Investasi dan Tantangan Biogas \& Biomassa (Bioenergi)}

Tantangan dalam pengembangan PLT Biogas \& Biomassa antara lain:

1) Capital investment pada awal project masih tinggi.

2) Jaminan keberlanjutan penyediaan bahan baku.

3) Jaminan kestabilan harga limbah biomassa (biomass fuel).

4) Kesiapan jaringan PLN dalam melakukan interkoneksi dengan pembangkit biomassa. 
Teknologi biogas plant yang berkembang di Indonesia dan telah diimplementasikan di beberapa wilayah terbagi atas dua yakni covered lagoon dan tangki anaerobic. Kedua desain teknologi disesuaikan dengan kondisi geografi, luas plant, dan kemudahan pengoperasiannya. Perbedaan penggunaan teknologi antara covered lagoon dan Tank reactor adalah sebagai berikut:

Tabel 4.

Kelebihan dan Kelemahan Tank Reaktor

\begin{tabular}{|c|c|}
\hline Kelebihan & Kelemahan \\
\hline $\begin{array}{l}\text { - Dapat digunakan untuk segala macam } \\
\text { jenis lahan. } \\
\text { - Luas lahan yang dibutuhkan relatif } \\
\text { kecil. } \\
\text { - Konsentrasi gas metana yang dihasilkan } \\
\text { relatif tinggi. }\end{array}$ & $\begin{array}{l}\text { - Biaya konstruksi relatif lebih tinggi. } \\
\text { - Relatif lebih sensitif terhadap } \\
\text { perubahan operasional. } \\
\text { - Penyimpanan gas yang relatif kecil. }\end{array}$ \\
\hline
\end{tabular}

\section{Kesimpulan}

Sebagai penghasil tanaman kelapa sawit terbesar di dunia, pemenuhan tenaga listrik dari limbah pabrik kelapa sawit sangat potensial di Indonesia. Dari kapasitas produksi pabrik sebesar 30 ton/jam Tandan Buah Segar (TBS) / Fresh Fruit Bunch (FFB) dapat menghasilkan tenaga listrik sebesar $1 \mathrm{MW}$ dari PLT Biogas (PLTBg) berasal dari POME. Dari sekitar 700 pabrik kelapa sawit secara nasional, dengan kapasitas produksi rata-rata 30 - 45 ton/jam TBS, secara umum dapat menghasilkan tenaga listrik sebesar 700 MW dari PLT Biogas (PLTBg).

\section{Daftar Pustaka}

Abimanyu Haznan dan Hedrana Sunit, 2014, Konversi Biomassa Untuk Alternatif Energi di Indonesia: Tinjauan Sumber Daya, Teknologi, Manajemen dan Kebijakan, Cetakan Pertama, LIPI Press, Jakarta

A., Imteaz, M.A., Arifuzzaman, 2020. Recent advances on palm oil mill effluent (POME) pretreatment and anaerobic reactor for sustainable biogas production. Renew.

Bala, J.D., J. Lalung, and N. Ismail., (2014). Palm Oil Mill Effluent (POME) Treatment Microbial Communities in an Anaerobic Digester: A Review.International Journal of Scientific and Research Publications, 4(6): 1 - 24

Direktorat Jenderal Energi Baru, Terbarukan, dan Konservasi Energi Kementrian ESDM , 2016, Investment Guidelines Bioenergy in Indonesia, tersedia pada https://ebtke.esdm.go.id/post/2019/01/31/2117/buku.investasi.bi oenergi.2016, Diakses 1 May 2021.

Hasanudin, U, R. Sugiharto, A. Haryanto, T. Setiadi, and K. Fujie., (2015). Palm Oil Mill Effluent Treatment and Utilization to Ensure the Sustainability of Palm Oil Industries. Water Science and Technolology, 72(7):1089-95.

Kusuma Aditya, Priciia Melisa, Agus Hadiyarto, 2012. Pemurnian Biogas dari Kandungan Hidrogen Sulfida dengan $\mathrm{NaOH}, \mathrm{CuSO} 4, \mathrm{Fe} 2(\mathrm{SO} 4) 3$ dalam Packed Column Secara Kontinyu, Jurnal Teknologi Kimia dan Industri, Vol. 1, No.1, Tahun 2012, Halaman 389-395.

Mufida, D. K., Sholichin, M., Cahyani, C., (2015). Perencanaan Instalasi Pengolahan Air Limbah (IPAL) Dengan Menggunakan Kombinasi Sistem Anaerobik-Aerobik Pada Pabrik Tahu "DUTA" Malang. Jurnal Pengairan 
Vol. 2, No. 3, pp $163-169$

doi: $10.14710 /$ jebt.2021.11163

Parinduri Luthfi, 2016, Analisa Pemanfaatan Biomassa Pabrik Kelapa Sawit Untuk Sumber Pembangkit Listrik, tersedia pada : https://jurnal.uisu.ac.id/index. php/jet/ article/view/201/172, Diakses 1 Mei 2021.

Suyitno, Agus Sujono, Dharmanto. (2010). Teknologi Biogas Pembuatan, Operasional, dan Pemanfaatan, Edisi Pertama

Shintawati, Hasanudin, U., Haryanto, A. (2017). Karakteristik Pengolahan Limbah Cair Minyak Kelapa Sawit dalam Bioreaktor Cigar Kontinu. Jurnal Teknik Pertanian Lampung, Vol. 6, No. 2, 81-88 